\title{
Włączenie pracowników dziekanatów w proces tworzenia aktów normatywnych. Uwarunkowania strukturalne i możliwości ich przekroczenia
}

\section{Streszczenie}

W 2018 r. powstało Stowarzyszenie Forum Dziekanatów, którego jednym z celów jest włączenie się $\mathrm{w}$ dialog $\mathrm{z}$ organizacjami i instytucjami zajmującymi się szkolnictwem wyższym, a zwłaszcza MNiSW jako właściwym organem administracji publicznej. W tym celu Stowarzyszenie sformułowało trzy propozycje zmian w ustawie Prawo o szkolnictwie wyższym i nauce w kontekście postępowania administracyjnego, w szczególności: zawiadomienia o wszczęciu postępowania, postępowania uproszczonego oraz milczącego załatwienia sprawy, które zostały przekazane do MNiSW. Powstanie Stowarzyszenia jako oddolnej inicjatywy pracowników dziekanatów szkół wyższych oraz innych osób zajmujących się obsługą toku studiów dało im możliwość uczestniczenia w konsultacji w zakresie prawa o szkolnictwie wyższym oraz formułowania postulatów jego zmiany. Jest to szczególnie istotne, biorąc pod uwagę, że na uczelniach pracownicy dziekanatów nie mają możliwości przekazania informacji zwrotnej na temat przepisów, które wykonują.

Słowa kluczowe: dziekanat, uczelnia, ustawa p.s.w.in., kodeks postępowania administracyjnego, MNiSW

1 Dr hab. Katarzyna Górak-Sosnowska - Szkoła Główna Handlowa w Warszawie; e-mail: kgorak@ sgh.waw.pl; ORCID: 0000-0002-1121-6240.

2 Mgr Ewa Wiśniewska-AkademiaLeona Koźmińskiego; e-mail: ewaw@kozminski.edu.pl; ORCID: 0000-0002-3572-7686. 


\title{
KATARZYNA GÓRAK-SOSNOWSKA, EWA WIŚNIEWSKA
}

\section{Including Employees of Dean's Offices in the Process of Development of Normative Acts. Structural Constraints and the Ways to Overcome Them}

\begin{abstract}
In 2018 Student Services Employee Association (Stowarzyszenie Forum Dziekanatów) was established. One of its aims is to get involved in a dialogue with organisations and institutions dealing with higher education, in particular with the Ministry of Science and Higher Education as the relevant public authority. In this regard the Association proposed three amendments to the Act of Higher Education and Science in terms of administrative procedure, in particular: notice on initiation of procedure, simplified procedure and silent settlement of case, which were submitted to the Ministry. As a bottom-up initiative of student services employees at HEIs, it enables them to get involved in consulting acts on higher education and proposing amendments to these regulations. This role of the Association is significant due to the fact that in many HEIs student services employees have no ability to provide feedback on the regulations that they are executing.
\end{abstract}

Keywords: dean's office, HEI, Law on Science and Higher Education, General Administrative Procedure Act, Ministry of Science and Higher Education 
W

przypadku szkół wyższych pracownicy jednostek administracji zajmujący się obsługą toku studiów na podstawie obowiązujących przepisów prawnych nieczęsto mają publicznie możliwość przedstawienia na ich temat swojej opinii, a zatem zaangażowania się $\mathrm{w}$ proces konsultowania wewnętrznych aktów normatywnych uczelni. Uczelniane akty normatywne opracowywane są przez jednostki centralne zajmujące się legislacją. Jednostki, które stają się końcowymi wykonawcami tych przepisów, bywają konsultowane, jednak dzieje się to stosunkowo rzadko. Nie jest to cecha właściwa wyłącznie szkołom wyższym, dotyczy bowiem wielu instytucji administracji publicznej, gdzie komunikacja przebiega głównie jednokierunkowo ${ }^{3}$. W niniejszym tekście będziemy chciały wykazać, że włączenie pracowników dziekanatów jako jednostek, które opierają swoją bieżącą pracę na tych przepisach, może przełożyć się na zwiększenie przejrzystości i efektywności procedur prawnych.

Artykuł nasz piszemy z perspektywy, która opiera się nie tylko na badaniach własnych, prowadzonych od ponad dwóch lat w dziekanatach polskich uczelni publicznych i niepublicznych, ale i na obserwacji uczestniczącej. Obie bowiem jesteśmy zaangażowane $\mathrm{w}$ proces upodmiotowienia, usieciowienia i integracji pracowników dziekanatów z całej Polski, który rozpoczął się podczas pierwszego ogólnopolskiego Forum Dziekanatów zorganizowanego w grudniu 2017 r. w Szkole Głównej Handlowej w Warszawie ${ }^{4}$, a sformalizowany został poprzez utworzenie w listopadzie 2018 r. Stowarzyszenia Forum Dziekanatów 5 .

\section{Od dziekanatu do stowarzyszenia}

Dziekanat jest jednostką administracyjną, a zatem pełni funkcję pomocniczą wobec organów uczelni. Jak pisze Radosław Sojak, „w szerokoprofilowych uniwersytetach dziekanaty stanowią najważniejszy niewykorzystany w pełni rezerwuar wiedzy o funkcjonowaniu uczelni i jednocześnie jeden z najistotniejszych poten-

3 K. Serafin, Skuteczna komunikacja w podmiotach administracji publicznej, „Studia Ekonomiczne” 2013, 141, s. 143.

$4 \quad$ Więcej na http://dziekanaty.pl

5 Więcej na http://forum-dziekanatow.pl 
cjałów pozytywnej zmiany instytucjonalnej"6. Projekty wewnętrznych aktów normatywnych uczelni czasami są konsultowane z pracownikami dziekanatów, jednak zależy to od struktury uczelni i jej kultury organizacyjnej. W dużych uczelniach, gdzie dziekanatów jest wiele, zadanie to przejmuje najczęściej jednostka administracji centralnej zajmująca się koordynacją procesu obsługi toku studiów.

Projekty ustaw i aktów wykonawczych są konsultowane z wieloma ciałami reprezentującymi uczelnie (np. Konferencją Rektorów Akademickich Szkół Polskich, Radą Główną Nauki i Szkolnictwa Wyższego). W przypadku uczelni zgłaszaniem uwag zajmuje się natomiast wyspecjalizowana jednostka (dział radców prawnych). Dobrą praktyką byłoby z pewnością włącznie do procesu przygotowywania uwag pracowników jednostek bezpośrednio zainteresowanych, tj. będących przyszłymi końcowymi wykonawcami przepisów prawnych, jednak wydaje się, że zdarza się to niezwykle rzadko.

Dowodem epizodycznym niechaj będzie wynik konsultacji społecznych dotyczących ustawy Prawo o szkolnictwie wyższym i nauce z dnia 20 lipca 2018 r. (dalej: p.s.w.in.) ${ }^{7}$. Jedna z norm nakłada na uczelnie obowiązek, któremu sprostanie będzie bardzo problematyczne. Chodzi nam o art. 7 ust. 2 ustawy, zgodnie z którym „w terminie 30 dni od dnia ukończenia studiów uczelnia wydaje absolwentowi dyplom ukończenia studiów wraz z suplementem do dyplomu oraz ich 2 odpisy, w tym na wniosek absolwenta-ich odpis w języku obcym". W przeciwieństwie do obowiązujących uprzednio przepisów, zarówno w ustawie, jak i w rozporządzeniu w sprawie studiów nie zawarto katalogu języków obcych. Oznacza to, że w świetle obowiązującego prawa student może wnioskować $\mathrm{w}$ dowolnym momencie, a uczelnia ma obowiązek wydania odpisu dyplomu i suplementu we wszystkich możliwych językach świata w terminie 30 dni od ukończenia studiów. Języków, które można zapisać, jest współcześnie około 4 tysięcy. Można jednak zdefiniować pojęcie ,język obcy" jeszcze szerzej obejmując języki martwe (np. ugarycki), sztuczne (np. kilgoński) lub takie, których się nie zapisuje (np. kaczyński).

Pomimo znaczenia tej normy i ewidentnych trudności z jej wdrożeniem (granice których wyznacza m.in. pomysłowość studentów) żadna instytucja biorąca udział w konsultacjach nie podniosła tej kwestii. Być może wynika to z tego, że poprzednio kwestię języków obcych regulowało rozporządzenie. W przypadku dyplomów obowiązywał zamknięty katalogjęzyków (mogły być wydawane w pięciu językach),

$6 \quad$ R. Sojak, Dziekanat w przestrzeni instytucjonalnej uniwersytetu - w stronę komunikacji symetrycznej, [w:] K. Górak-Sosnowska, R. Pajewska-Kwaśny (red.), Dziekanat w procesie zmian. Nowa rzeczywistość prawna i organizacyjna, Warszawa 2019.

7 Ustawa Prawo o Szkolnictwie Wyższym i Nauce z dnia 20 lipca 2018 r. (Dz.U. z 2018 r., poz. 1668). 
natomiast suplementy były wydawane wyłącznie w języku angielskim ${ }^{8}$. Postulat zmiany tego przepisu pojawił się dopiero przy okazji konsultacji publicznych dotyczących Rozporządzenia w sprawie studiów ${ }^{9}$ i opiniowania ${ }^{10}$. Na tym etapie było już jednak za późno ze względu na brak delegacji ustawowej.

Przedstawiony przez nas przykład przeoczenia błędu w ustawie nie jest oczywiście wystarczającym argumentem za włączeniem pracowników dziekanatów do konsultacji. Trudno bowiem przewidzieć, czy - gdyby pracownicy dziekanatów zostali włączeni w proces konsultacji publicznych w ramach swoich uczelni - zauważyliby ten problem już na poziomie projektu ustawy. Można też podnieść argument, że przecież każdy pracownik dziekanatu jest osobą fizyczną i mógł zgłosić uwagę. Obrazu dopełnia jednak zaangażowanie pracowników dziekanatów w formułowanie uwag i postulatów zarówno do projektu ustawy, jak i rozporządzenia, gdy pojawiła się ku temu sposobność w pozauczelnianej rzeczywistości; wówczas kwestia wydawania odpisów dyplomów i suplementów w językach obcych była jedną z najczęściej i najgłośniej podnoszonych ${ }^{11}$.

Pojawiają się zatem dwa powiązane ze sobą pytania. Pierwsze z nich brzmi: dlaczego pracownicy dziekanatów nie biorą udziału w procesie tworzenia projektów aktów normatywnych w swoich uczelniach albo robią to epizodycznie? Wydaje się, że odpowiedź na to pytanie wynika ze struktury uczelni. W administracji szkół wyższych dziekanaty zajmują miejsce pośrednie. $Z$ jednej strony są centralnymi jednostkami w swoich jednostkach organizacyjnych, z drugiej zaś podlegają jed-

8 Dotychczas dyplomy mogły być wydawane w pięciu językach - angielskim, niemieckim, francuskim, hiszpańskim lub rosyjskim w terminie $30 \mathrm{dni}$ od dnia złożenia wniosku. Suplementy były wydawane wyłącznie w tłumaczeniu na język angielski. Katalog języków obcych, w których mogą być wydawane dyplomy, był określony w $§ 11$ ust. 2 uchylonego Rozporządzenia w sprawie dokumentacji przebiegu studiów. Nie było katalogu języków obcych, w których uczelnia może wydać odpis suplementu. Uczelnie wydawały suplementy w języku angielskim na podstawie uchylonego Rozporządzenia w sprawie tytułów zawodowych nadawanych absolwentom studiów, warunków wydawania oraz niezbędnych elementów dyplomów ukończenia studiów i świadectw ukończenia studiów podyplomowych oraz wzoru suplementu dyplomu. We wzorze suplementu stanowiącego załącznik do ww. rozporządzenia został określony jedynie wymóg, że w przypadku tłumaczenia na język angielski tytuł zawodowy należy wpisać w oryginalnym brzmieniu.

9 Uwagi zgłoszone przez 5 podmiotów - Dział Organizacyjno-Prawny UMCS, poz. 133, osobę fizyczną nr 5, poz. 134, KRAUM - Śląski Uniwersytet Medyczny w Katowicach, poz. 137, KRAUM - Uniwersytet Medyczny w Białymstoku, poz. 138 i Uniwersytet Jagielloński, poz. 139. Por. Raport z konsultacji publicznych i opiniowania projektu rozporządzenia Ministra Nauki i Szkolnictwa Wyższego w sprawie studiów, MNiSW, 17.09.2018.

10 KRASP, poz. 53 - por. Zestawienie uwag do projektu rozporządzenia Ministra Nauki i Szkolnictwa Wyższego w sprawie studiów zgłoszonych w ramach opiniowania, MNiSW, 17.09.2018.

11 Np. tu: Zaproszenie na seminarium poświęcone pracy dziekanatów w kontekście Ustawy 2.0. Kraków 25- 26.03.2019, http://forum-dziekanatow.pl/index.php/zaproszenie-na-seminariumposwiecone-pracy-dziekanatow-w-kontekscie-ustawy-2-0-krakow-25-26-03-2019/ 
nostkom administracji centralnej. Te ostatnie nadają kształt relacjom między nimi a dziekanatami, a ponadto wyznaczają zadania i procedury na poziomie całej uczelni. Jak wskazuje R. Sojak, między administracją centralną a dziekanatami występują zasadnicze bariery. Są to: (a) podległość dziekanatów jednostkom administracji centralnej, (b) asymetria komunikacyjna z dominującą pozycją administracji centralnej ustalającej reguły gry oraz (c) organizacyjna niekompatybilność - dziekanaty są wielozadaniowe, zaś jednostki administracji centralnej wąsko wyspecjalizowane $^{12}$.

Wydaje się, że zwłaszcza ta ostatnia bariera ma znaczenie, jeżeli chodzi o możliwość wpływu pracowników dziekanatu na wewnętrzne akty normatywne, na których opierają swoją bieżącą pracę w zakresie obsługi toku studiów. Konieczność orientacji w przepisach prawa zdaje się umykać w szerokim profilu działalności dziekanatu, a wyspecjalizowane w zakresie prawa jednostki administracji centralnej zdają się posiadać wystarczającą wiedzę i kompetencje. Co więcej, dziekanatów na jednej uczelni może być kilka, czy nawet kilkanaście - konsultowanie z nimi może oznaczać uzyskanie wielu sprzecznych opinii. Warto bowiem pamiętać, że o ile kierownicy jednostek znają się chociażby poprzez zaangażowanie w zespoły o strategicznym znaczeniu dla uczelni (rady dyscyplin, rady kierunków, komisje rektorskie i in.), kierownicy dziekanatów (nie mówiąc o całych dziekanatowych zespołach) funkcjonują w oderwaniu od siebie, mimo tego, że są na jednej uczelni, mają ten sam zakres zadań i obowiązują ich te same uczelniane regulacje ${ }^{13}$.

Drugie powiązane z pierwszym pytanie brzmi: dlaczego pracownicy dziekanatów, jako członkowie Stowarzyszenia, angażują się w proces konsultowania projektów aktów prawnych poza swoimi uczelniami? Wydaje się nam, że w ten sposób omijają opisaną powyżej barierę strukturalną, a z kolei zbyt dobrze znają konsekwencję wprowadzania przepisów prawnych, czy to wewnątrzzakładowych, czy powszechnych, ponieważ muszą je stosować w swojej pracy. Niejednokrotnie zdarza się, że pracownicy dziekanatu muszą decydować o sposobie ich interpretacji, co skutkuje odmiennymi decyzjami w podobnych sprawach nawet $\mathrm{w}$ tej

12 R. Sojak, op. cit.

13 Anegdotycznie można wspomnieć, że zinstytucjonalizowana współpraca między dziekanatami na Politechnice Warszawskiej zapoczątkowana została 2 lata temu. Podobna inicjatywa na Uniwersytecie im. Adama Mickiewicza pojawiła się kilka miesięcy temu, a na Uniwersytecie Mikołaja Kopernika dopiero się tworzy. W obu przypadkach impulsem do nawiązania współpracy było I ogólnopolskie Forum Dziekanatów. Więcej na ten temat por. A. Stoczkiewicz, L. Szypulska-Czkwianianc, Zasady wspótpracy administracji centralnej z dziekanatami na przykładzie Politechniki Warszawskiej, [w:] K. Górak-Sosnowska, R. Pajewska-Kwaśny (red.), op. cit. oraz J. Grądziel-Wójcik, Dziekanat a jakość ksztatcenia. Dobre praktyki Wydziału Filologii Polskiej i Klasycznej UAM, [w:] ibidem. 
samej uczelni. Zinstytucjonalizowanym kanałem umożliwiającym im artykułowanie swoich postulatów okazało się Stowarzyszenie Forum Dziekanatów.

Celem naszego Stowarzyszenia jest integracja środowiska pracowników administracyjnych uczelni, służąca wymianie doświadczeń i usprawnieniu pracy oraz uzyskanie w pływu na swoje środowisko pracy, stając się realnym głosem w dyskusjach na temat szkolnictwa wyższego, a w szczególności dotyczącego obsługi toku studiów. Obecnie Stowarzyszenie liczy 123 członków pracujących w ponad 40 uczelniach publicznych i niepublicznych.

Tworząc Stowarzyszenie, zakładaliśmy, że drugi cel - rzecznictwo w sprawach dotyczących dziekanatów - będzie szczególnie trudny do osiągnięcia i traktowaliśmy go jako dalekosiężny. Wkrótce jednak okazało się, że istnieją zarówno formalne, jak i nieformalne kanały do artykułowania naszych postulatów. Pierwszym są wspomniane konsultacje publiczne, w których jako stowarzyszenie możemy brać udział. Dotychczas zgłosiliśmyuwagi do jednego rozporządzenia - w sprawie studiów. Drugim okazała się współpraca z Departamentem Szkolnictwa Wyższego w Ministerstwie Nauki i Szkolnictwa Wyższego (dalej: MNiSW), efektem której stało się seminarium dedykowane pracownikom dziekanatów poświęcone nowym przepisom dotyczącym szkolnictwa wyższego, które odbyło się w marcu 2019 r. Program tego seminarium został opracowany na podstawie pytań i postulatów sformułowanych przez pracowników dziekanatów oraz inne osoby zajmujące się obsługą toku studiów - nie tylko naszego stowarzyszenia, ale także zamkniętej grupy na Facebooku „Forum Dziekanatów”, która liczy obecnie ponad 0,7 tys. członków.

Choć w dalszej części tekstu koncentrujemy się na jednym z przykładów naszej działalności - postulowaniu zmian w zakresie ustawy Kodeks postępowania administracyjnego (dalej: k.p.a.), warto wspomnieć, że nie jest to jedyny obszar, w którym podejmujemy działania. Latem 2019 r. z Komisją ds. USOS, funkcjonującą w ramach Międzyuniwersyteckiego Centrum Informatycznego, rozpoczęliśmy pracę nad standardem elektronicznej teczki studenta ${ }^{14}$, na bieżąco reagujemy na zmiany przepisów, które dotyczą naszej pracy lub prosimy MNiSW o interpretację tych obowiązujących ${ }^{15}$.

14 Rozporządzenie MNiSW w sprawie studiów z dnia 28.09.2018 z późn. zm. (Dz.U. z 2018 r., poz. 1861) dopuszcza możliwość prowadzenia dokumentacji przebiegu studiów w postaci elektronicznej-por. §15 i §19. Więcej na temat tej inicjatywy por. K. Górak-Sosnowska, Urealniamy e-teczkę - rozpoczynamy wspótpracę z MUCI, blog Stowarzyszenia Forum Dziekanatów, 11.07.2019, http:// forum-dziekanatow.pl/index.php/urealniamy-e-teczke-rozpoczynamy-wspolprace-z-muci/

15 Dwa przykłady to 1) kwestia ewidencjonowania hologramów potwierdzających ważność legitymacji studenckich, która - dzięki naszej interwencji - doczekała się sprostowania ze strony MNiSW oraz 2) opinia MNiSW w sprawie wymagania przez uczelnie zwrotu legitymacji przez 


\section{Kodeks postępowania administracyjnego z perspektywy dziekanatu}

Na podstawie doświadczenia w zakresie obsługi toku studiów sformułowaliśmy trzy postulaty zmian $\mathrm{w}$ ustawie p.s.w.in., które pozwoliłyby na uproszczenie postępowania administracyjnego, a tym samym odbiurokratyzowanie pracy dziekanatów i podniesienie jakości obsługi studenta ${ }^{16}$. Postulaty te zostały sformułowane i przekazane do MNiSW przez nasze Stowarzyszenie ${ }^{13}$ jako działanie oddolne będące sposobem na zaangażowanie się w konsultacje prawa o szkolnictwie wyższym, inaczej nieosiągalne dla pracowników dziekanatów.

Niedawno dokonane zmiany przepisów prawnych zarówno ustawy Kodeks postępowania administracyjnego, jak i p.s.w.in. nie w pełni przyczyniły się do odbiurokratyzowania dziekanatów. Przepisy k.p.a. nie do końca uwzględniają specyfikęuczelni, zaś przepisy p.s.w.in. w opisanych poniżej obszarach nie doprecyzowują albo nie określają kwestii związanych z postępowaniem administracyjnym. W myśl zasady efektywności prowadzenie postępowania administracyjnego powinno odbywać się w sposób najmniej uciążliwy dla obu stron, zachowując zarazem minimalne wymogi proceduralne gwarantujące jednostce ochronę jej praw ${ }^{17}$. Szybkie załatwianie spraw to jedno z podstawowych oczekiwań wobec nowoczesnej administracji, a tym samym nowoczesnego dziekanatu. Czas postępowania administracyjnego w indywidualnych sprawach studentów mógłby być znacznie skrócony, gdyby istniała możliwość dokonania niewielkich zmian w przepisach ustawy p.s.w.in. doprecyzowujących i wprowadzających rozwiązania dopuszczone przez przepisy k.p.a. W szczególności sprawy te dotyczą:

1) zawiadomienia o wszczęciu postępowania,

2) postępowania uproszczonego,

3) milczącego załatwienia sprawy.

studentów po obronie (która wynika z przepisów wewnątrzuczelnianych, a nie powszechnych). Więcej na ten temat por. E. Wiśniewska, Sprostowanie MNiSW w sprawie rejestru hologramów, blog Stowarzyszenia Forum Dziekanatów, 23.09.2019, http://forum-dziekanatow.pl/index.php/sprostowanie-mnisw-w-sprawie-rejestru-hologramow/; E. Wiśniewska, Legitymacja może być pamiątkg po studiach, blog Stowarzyszenia Forum Dziekanatów, 18.09.2019, http://forum-dziekanatow.pl/ index.php/zwrot-legitymacji-moze-byc-przeszloscia/

16 Więcej na temat postępowania administracyjnego w sprawach studentów por. P. Dańczak, Decyzja administracyjna w indywidualnych sprawach studentów i doktorantów, Warszawa 2015 (rozdział II-IV).

17 Merytorycznie postulaty opisała w liście do MNiSW Ewa Wiśniewska. 
Postulaty i propozycje rozwiązań formułujemy z perspektywy codziennych zadań wykonywanych przez pracowników dziekanatów z uwzględnieniem obowiązujących przepisów. Z perspektywy uczelni jako całości mogą mieć one znacznie drugorzędne - skoro odpowiedzialne za ich realizację jednostki je wykonują - jeżeli jednak udałoby się je wprowadzić w życie, mogłoby przyczynić się do podwyższenia jakości pracy dziekanatów i środowiska pracy ich pracowników. Efektem końcowym byłoby zwiększenie jakości obsługi studenta, a zatem korzyść odniosłaby cała uczelnia.

\section{Zawiadomienia o wszczęciu postępowania (art. 108 ust. 3 p.s.w.in.)}

Art. 108 ust. 3 p.s.w.in. nakłada na organy uczelni obowiązek skreślenia studenta $\mathrm{w}$ drodze decyzji administracyjnej regulowanej przepisami k.p.a. Mając na uwadze przede wszystkim specyfikę relacji między studentem a uczelnią, a także nakład pracy związany z generowaniem zawiadomień o wszczęciu postępowania - który sam $\mathrm{w}$ sobie nie byłby argumentem - wydaje się zasadne rozważenie wprowadzenia uproszczeń $\mathrm{w}$ tym zakresie ${ }^{14}$. Zdajemy sobie sprawę $\mathrm{z}$ tego, że przepisy k.p.a. dotyczące decyzji administracyjnych zostały skonstruowane $\mathrm{w}$ taki, a nie inny sposób, m.in. po to, aby strona w sprawie, której toczone jest postępowanie miała czas i możliwości, aby odpowiednio zareagować. Wydaje się nam jednak, biorąc pod uwagę specyfikę uczelni i specyfikę wydawanych przez jej organy decyzji w indywidualnych sprawach studentów, że proces ten mógłby być uproszczony. Przemawia za tym wiele argumentów ${ }^{18}$, które determinują różnice w relacjach organuuczelni ze stroną postępowania (w naszym przypadku studentem, a nie anonimowym petentem) a organem administracji publicznej:

$\square$ inny jest charakter relacji - student jest członkiem społeczności akademickiej, studiuje w uczelni kilka lat, ma zazwyczaj przypisaną konkretną osobę $\mathrm{w}$ dziekanacie, która zajmuje się jego sprawami ${ }^{19}$, i nierzadko jest znany z imienia i nazwiska. Nie jest zatem anonimowy tak jak np. petent $w$ urzędzie miasta/dzielnicy, który często z tego urzędu nie korzysta, a sam urząd może nie dysponować danymi do kontaktu poza adresem zamieszkania; w większości uczelni student otrzymuje indywidualne konto e-mail, z którego zobowiązany jest regularnie korzystać w kontaktach z uczelnią;

18 Szerzej piszemy o tym w: E. Wiśniewska, K. Górak-Sosnowska, Dylematy postępowania administracyjnego w szkołach wyższych na gruncie obowiązujących przepisów prawnych, [w:] K. Górak-Sosnowska, R. Pajewska-Kwaśny (red.), op. cit.

19 K. Górak-Sosnowska, J. Brdulak, M. Matusewicz, I. Senator, Dziekanaty na wyższych uczelniach. Funkcjonowanie - wyzwania - dobre praktyki, Warszawa 2018. 
$\square$ student może bezpośrednio zwrócić się do kierownika jednostki administracyjnej albo złożyć odpowiedni wniosek w dziekanacie;

przesłankiskreślenia doprecyzowują regulaminystudiów, organizacja roku akademickiego, znane są terminy wnoszenia opłat czy składania prac dyplomowych. Z informacjami tymi student zobowiązany jest zapoznać się, co wynika zazwyczaj z regulaminu studiów.

Mimo że k.p.a. dopuszcza wysyłanie zawiadomień drogą elektroniczną, tofunkcjonujące $\mathrm{w}$ wielu uczelniach systemy informatyczne nie spełniają takich kryteriów, aby doręczenie mogło zostać uznane za skuteczne ${ }^{20}$. Pozostaje więc podstawowa forma doręczeń pism, czyli list polecony za zwrotnym potwierdzeniem odbioru. Proces ten jest nieefektywny ${ }^{21}$, stosunkowo kosztowny (biorąc pod uwagę skalę postępowań, w szczególności skreśleń) ${ }^{22}$, ale przede wszystkim praco- i czasochłonny, a niekiedy wewnętrznie sprzeczny ${ }^{23}$.

20 Z naszych obserwacji wynika, że większość uczelni stosuje pełną procedurę administracyjną, wysyłając zawiadomienia w tradycyjnej formie. Jeżeli niektóre uczelnie tego nie robią (decydując się na wysłanie zawiadomienia za pomocą uczelnianej poczty elektronicznej), to zazwyczaj nie dlatego, że dysponują odpowiednim systemem teleinformatycznym, ale wychodzą z odmiennego założenia: porównują koszt potencjalnych spraw sądowych z tytułu niedopełnienia proceduralnego do kosztu obsługi administracyjnej wysyłania zawiadomien. W strategii drugiej radcy prawni obawiają się konsekwencji ze strony organów nadzoru i kontroli, więc decydują się na wdrożenie pełnej procedury.

21 W szczególności w przypadku skreśleń z powodu niewniesienia opłat studenci często nie reagują na zawiadomienie o wszczęciu postępowania i dopiero po otrzymaniu decyzji o skreśleniu dokonują zaległych opłat i składają odwołanie z prośbą o uchylenie decyzji. De lege lata w przypadku, gdy w wyniku doręczenia zawiadomienia o wszczęciu postępowania okaże się, że brak jest podstaw do skreślenia z listy studentów, bo np. student wniósł opłatę, to zgodnie z k.p.a. uczelnia powinna wydać decyzję o umorzeniu postępowania zgodnie z art. 105 k.p.a., co z kolei prowadzi to kolejnego wzrostu biurokracji i konieczności doręczania kolejnych decyzji i generowania kolejnych kosztów.

22 Wysłanie ekonomicznego listu poleconego za potwierdzeniem odbioru to koszt 8,50 zł. W przypadku zawiadomienia o wszczęciu postępowania i wysłania decyzji jest to koszt 17 zł na każdego skreślanego studenta.

23 Dotyczy to najczęściej obligatoryjnych podstaw do skreślenia. Na przykład: student nie złożył na czas pracy dyplomowej, a regulamin studiów nie przewiduje wydłużenia tego terminu. Zawiadamiamy zatem studenta o postępowaniu w sprawie skreślenia i wzywamy do wniesienia wyjaśnień, tymczasem, jakie one by nie były, przesłanka do skreślenia pozostaje taka sama. Jeżeli student nie kontynuował studiów, a skończył się semestr, również - niezależnie od przyczyn - powinien zostać skreślony z listy studentów. W takich przypadkach złożenie jakichkolwiek wyjaśnień nie wpłynie na wynik rozstrzygnięcia sprawy. Wzywanie studenta do złożenia wyjaśnień (zgodnie z k.p.a.) powoduje czasami nieprzyjemne sytuacje - student wierzy, że złożywszy wyjaśnienia, ma szansę na zmianę swojej sytuacji, tymczasem wezwanie do złożenia wyjaśnień jest jedynie formalnością, która nic nie zmienia. Oczywiście inaczej sytuacja wygląda w przypadku fakultatywnych podstaw do skreślenia, np. za niewniesienie opłat, gdy uczelnia może, ale nie musi 
Czas, od momentu wysłania zawiadomienia o wszczęciu postępowania do momentu, kiedy decyzja o skreśleniu staje się ostateczna, wynosi około dwa miesiące, a pracownicy dziekanatu dwukrotnie wypełniają zwrotki oraz co najmniej trzykrotnie śledzą terminy tj. termin odbioru zawiadomienia i możliwości ustosunkowania się studenta do sprawy, termin kiedy można wydać decyzję, termin odbioru decyzji i termin na odwołanie się aż do momentu, kiedy decyzja staje się ostateczna.

Skutki wydłużonego procesu skreśleń mają bezpośredni wpływ nie tylko na pracę dziekanatu (i uczelni), ale i na studentów, i to zarówno podlegających tej procedurze. jaki tych, którzy wywiązali się z wszystkich obowiązków studenckich i tej procedurze nie podlegają. W przypadku studentów podlegających procedurze skreślenia:

$\square$ do chwili zakończenia postępowania administracyjnego w swojej sprawie student zachowuje status studenta. To z jednej strony powoduje, że w jej trakcie są naliczane opłaty za studia (w przypadku płatnych studiów, albo dodatkowych usług edukacyjnych - np. opłaty za powtarzanie zajęć czy semestru), mimo iż często powodem skreślenia są zaległości wynikające z trudnej sytuacji finansowej studenta. $Z$ drugiej strony, student jest uprawniony do pobierania stypendium, co może stać się przedmiotem nadużyć,

$\square$ jest to proces długotrwały - od wszczęcia postępowania do czasu, kiedy student otrzymuje decyzję o skreśleniu, w najlepszym przypadku mija półtora miesiąca,

- list polecony może odebrać inna osoba (domownik uprawniony do odbioru przesyłki), co skutkuje nieporozumieniami z rodzicami studentów.

Na czaso- i pracochłonności procedury skreślenia tracą inni studenci, którym pracownicy dziekanatu mogą poświęcić mniej czasu.

Powyższe argumenty przemawiają za tym, aby podjąć dyskusję na temat możliwości uproszczenia procedury wysyłania zawiadomień o wszczęciupostępowania, tak aby zredukować nadmierny formalizm w tym procesie. Warto byłoby zatem rozważyć możliwość zawiadamiania studenta mailem na indywidualne uczelniane konto przydzielone przez uczelnię (czyli dopuszczenie możliwości braku potwierdzenia odbioru pisma).

Wysyłając zawiadomienie o wszczęciu postępowania mailem, z pewnością nie ograniczymy praw studenta, nawet jeśli zdarzyłaby się sprawa błędnie rozpoznana, a student by nie odebrał zawiadomienia o wszczęciu postępowania, ma on nadal

skreślać, a wniesienie wyjaśnień (i uregulowanie należności) może zmienić bieg sprawy. W tych przypadkach powinniśmy powiadomić studenta. 
prawo do obrony poprzez złożenie odwołania od wydanej decyzji. Nie rodzi to negatywnych skutków dla studenta-zachowuje on przecież swoje prawa do momentu, kiedy decyzja staje się ostateczna (po upływie odpowiednich terminów na doręczenie i odwołanie od decyzji).

Z doświadczenia wiemy, że odebranie pisma wysłanego tradycyjną pocztą nie gwarantuje jego dostarczenia do adresata, a tym bardziej przeczytania - potwierdzenie odbioru (zwrotka) jedynie potwierdza fakt dostarczenia pisma na wskazany adres. Pracując ze studentami, widzimy, że e-mail stał się skuteczniejszą formą doręczenia, bowiem potwierdza dostarczenie pisma do konkretnej osoby. Kwestia przeczytania jest już odrębna w obydwu przypadkach.

Możliwość wysyłania zawiadomień mailem znacznie usprawniłaby pracę dziekanatów i zniwelowałaby negatywne skutki przedłużającej się procedury dla studenta. Ponadto dla samego studenta wydaje się to mieć inne pozytywne skutki. Są to:

brak konieczności odbierania przesyłek w tradycyjnej formie (listonosz, poczta, awizo),

$\square$ dostosowanie do potrzeb coraz bardziej mobilnych studentów korzystających z nowych technologii,

niwelacja zagrożenia, że przesyłkę odbierze ktoś inny,

$\square$ efektywniejsza obsługa studenta.

\section{Postępowanie uproszczone (art. 163b-163g k.p.a.)}

Zgodnie z art. 163b postępowanie w trybie uproszczonym może toczyć się wyłącznie w sytuacji, gdy w przepisach ustawy szczególnej stanowiącej normatywne podstawy rozstrzygnięcia istnieje przepis, który dopuszcza w danej sprawie tryb uproszczony. Zgodnie z art. 108 ust. 3 ustawy p.s.w.in. skreślenie studenta następuje w drodze decyzji administracyjnej, co oznacza, że do decyzji administracyjnych wydawanych na podstawie art. 108 ust 1 i 2 powinniśmy stosować przepisy k.p.a. wprost, a nie "odpowiednio" jak dotychczas ${ }^{24}$.

Biorąc pod uwagę specyfikę relacji student - uczelnia (por. wyżej), ale także specyfikę prowadzonych spraw studenckich i obsługi studentów przez dziekanaty, stosowanie k.p.a. wprost mogłoby oznaczać w skrajnym przypadku, że zabieramy

24 Więcej na ten temat por. M. Hauser, Odpowiednie stosowanie przepisów prawa. Uwagi porządkujące, „Przegląd Prawa i Administracji”, 2005, 45. 
studentom wzory podań i prowadzimy rozbudowane postępowanie dowodowe $e^{25}$, co oznaczałoby znaczne wydłużenie całej procedury i uciążliwości zarówno po stronie studenta, jak i dziekanatu. Wskazane byłoby zatem doprecyzowanie art. 108 ust. 3 poprzez dodanie przepisu, że "do postępowania w sprawie, o której mowa $\mathrm{w}$ art. 108 ust. 3 stosuje się przepisy k.p.a. o postępowaniu uproszczonym"26.

Należy podkreślić, że chociaż przepisy ustawy nie dopuszczają możliwości stosowania postępowania uproszczonego, to uczelnie i tak częściowo stosują ten tryb z uwagi na specyfikę prowadzonych spraw. Rozstrzygnięcia w sprawach studenckich są raczej standardowe i schematyczne, studenci wnoszą sprawy na standardowych formularzach dostępnych na stronach internetowych uczelni albo przy wykorzystaniu komunikacji elektronicznej. W sprawach studentów nie prowadzi się skomplikowanego postępowania dowodowego, bo większość dowodów w sprawie jest w posiadaniu uczelni (student może dołączyć dodatkowe zaświadczenia). To wszystko przemawia za prowadzeniem postępowania w trybie uproszczonym, a doprecyzowanie przepisu „zalegalizowałoby" ten sposób procedowania.

\section{Milczące załatwianie sprawy (art. 122a-122g)}

Alternatywą dla tradycyjnego modelu zakończenia postępowania decyzją jest milczące załatwienie sprawy, o którym mowa w rozdziale 8a k.p.a. oraz w przepisach dotyczących postępowania uproszczonego. „Milczenie” polega na tym, że organ w wyniku analizy sprawy może uznać, że wniosek zasługuje na uwzględnienie w całości, i nie podejmować żadnych działań. Brak działania organu w określonym czasie oznacza, że sprawa została załatwiona zgodnie ż̇ądaniem strony. Gdy sprawa zostanie załatwiona milcząco, organ nie wydaje decyzji lecz sporządza adnotację o treści rozstrzygnięcia i podstawie prawnej, którą zamieszcza w aktach sprawy.

Zdajemy sobie sprawę z tego, że w przypadku rezygnacji ze studiów postulat ten nie jest jednoznaczny: istnieją argumenty przemawiające za dopuszczalnością regulacjirezygnacji ze studiów w sposób milczący (milczenie jako ukierunkowanie na wywołanie konkretnych skutków materialnoprawnych, tu: ustanie stosunku

25 Z taką interpretacją spotkaliśmy się w przynajmniej jednym dziekanacie, w którym pracownicy zastanawiali się, w jaki sposób zapewniać studentom czynny udział w postępowaniu i wzywać ich (w jaki sposób?) na określoną godzinę do dziekanatu, aby zapoznali się z materiałem dowodowym.

26 Stosowanie postępowania uproszczonego z k.p.a. przydałoby się nie tylko przy skreśleniach, ale przy wszystkich sprawach, w których wydawane są decyzje administracyjne, np. odmowa przyjęcia na studia (art. 72 ust. 3 p.s.w.in.) albo zwolnienie cudzoziemca z opłat (art. 324 ust. 1 p.s.w.in.). 
administracyjnoprawnego ${ }^{27}$; milczące załatwienie sprawy stanowi alternatywę dla klasycznego modelu zakończenia postępowania administracyjnego decyzją ${ }^{28}$ ), jak i przeciw (milczące załatwienie sprawy nie nadaje się do stosowania w każdej sprawie ${ }^{29}$; milczące załatwienie sprawy może być zastosowane w sprawach wszczętych na żądanie strony, o ile jego efektem będzie uprawnienie lub korzyśćc $\left.{ }^{30}\right)^{31}$.

Naszym zdaniem warto jednak rozważyć, czy zastosowanie przepisu dotyczącego milczącego załatwienia sprawy można zastosować do rezygnacji ze studiów w sytuacji, kiedy organ uczelni w całości uwzględnia żądanie studenta. Dopusz-

$27 \mathrm{~W}$ doktrynie wskazuje się, że „(...) w rozumieniu prawa materialnego milczenie organu jest wyraźnie przyzwolone przez prawo i ma na celu tworzenie, przekształcanie lub usuwanie podstawowych stosunków materialnoprawnych" (K. Sobieralski, Milczenie jako prawna forma niedziatania administracji - konsekwencje procesowe, [w:] J. Korczak (red.), Cywilizacja administracji publicznej, Wrocław 2018, s. 450). W tym ujęciu milczenie organu ukierunkowane jest na wywołanie konkretnych skutków materialnoprawnych, zaś jednym z rodzajów tych skutków może być usunięcie (ustanie) stosunku administracyjnego. Potwierdza ten fakt brzmienie art. 1 pkt 1 k.p.a., zgodnie z którym k.p.a. normuje postępowanie przed organami administracji publicznej w należących do właściwości tych organów sprawach indywidualnych rozstrzyganych w drodze decyzji administracyjnych albo załatwianych milcząco. $Z$ woli ustawodawcy oznacza to bowiem, że są to dwa równorzędne sposoby załatwienia sprawy indywidualnej. Nie ma zatem przeszkód, żeby rezygnacja ze studiów przyjęła postać milczącego załatwienia sprawy.

28 W tym wypadku można odwołać się do uzasadnienia projektu nowelizacji k.p.a., w wyniku której doszło do unormowania w k.p.a. Działu II. Rozdziału 8a. Milczące załatwienie sprawy. Mianowicie, projektodawca zmian wskazał, że: po pierwsze, instytucja milczącego załatwienia sprawy ma na celu przyspieszenie i uproszczenie postępowania administracyjnego,jakrównieżusprawnienie i zmniejszenie kosztów funkcjonowania administracji. Po drugie, stanowi ona alternatywę dla klasycznego modelu zakończenia postępowania administracyjnego decyzją (Rządowy projekt ustawy o zmianie ustawy - Kodeks postępowania administracyjnego oraz niektórych innych ustaw, druk nr 1183, s. 45). A więc tam, gdzie ma być wydawana decyzja, może zostać to zastąpione konstrukcją milczenia organu, oczywiście jeżeli istnieje podstawa normatywna w przepisach szczególnych.

29 Sam projektodawca zmian, konkretyzując ratio legis w prowadzenia milczącego załatwienia sprawy, podkreśla, że jest to instytucja, która z natury rzeczy nie nadaje się do stosowania w każdej sprawie (ibidem, s. 46).

30 W doktrynie podkreśla się, że milczące załatwienie sprawy „(...) stosuje się jedynie w sprawach, w których postępowanie wszczęto na żądanie strony (art. 122a § 2 pkt 1) lub w sprawach zainicjowanych czynnością materialnoprawną jednostki, taką jak zgłoszenie lub zawiadomienie, podjętą w oczekiwaniu zaspokojenia jej interesu prawnego, a w konsekwencji - spełnienia kryjącego się za tą czynnością żądania (art. 122a § 2 pkt 2). W każdym z tych przypadków chodzi o ukształtowanie uprawnienia, czyli włączenie do porządku prawnego normy jednostkowej i konkretnej powodującej jakiegoś rodzaju przysporzenie po stronie jej adresata (uzyskanie przez niego korzyści w sensie prawnym)" (W. Chrościelewski, Z. Kmieciak (red.), Kodeks postępowania administracyjnego. Komentarz, Lex2019). Zatem w ślad za tym poglądem należy wykluczyć stosowanie milczącego załatwienia sprawy odnośnie do rezygnacji ze studiów, gdyż nie jest to akt kształtujący uprawnienie i/lub przysparzający stronie jakąś korzyść w znaczeniu prawnym.

31 Za przytoczenie argumentów zai przeciw dziękujemy dr. hab. Janowi Chmielewskiemu z Kolegium Prawa Akademii Leona Koźmińskiego. 
czalność stosowania konstrukcji milczącego załatwienia sprawy wymaga wprowadzenia stosownego przepisu szczególnego w ustawie p.s.w.in.

Przedstawione przez nas argumenty uzasadniające potrzebę nowelizacji ustawy p.s.w.in. w kontekście aplikacji przepisów k.p.a. stanowią jedynie pewną egzemplifikację szerszego problemu, jakim jest dopuszczenie wykonawców przepisów do udzielenia informacji zwrotnej, wysunięcia postulatów czy wyrażenia opinii na temat tego, co prawo będzie stanowiło.

Utworzenie stowarzyszenia zrzeszającego pracowników dziekanatów szkół wyższych domyka pewien obieg informacji. Prawo dotyczące szkolnictwa wyższego stanowione jest na poziomie państwa i opiniowane lub konsultowane przez szkoły wyższe i ich organizacje. Uzyskana informacja zwrotna nie jest jednak często pełna, albowiem nie uwzględnia głosu pracowników dziekanatów, którzy są końcowymi odbiorcami tworzonych regulacji na uczelniach. Znajdują się oni na najniższym szczeblu w uczelnianej hierarchii, pełniąc rolę administracyjną i usługową wobec podstawowej działalności uczelni. Ponadto, opiniowaniem lub konsultowaniem przepisów prawa zajmują się wyspecjalizowane działy administracji centralnej uczelni, które mogą, ale nie muszą, konsultować się z jednostkami administracyjnymi prowadzącymi kierunki studiów. Co więcej, wielość jednostek administracji uczelni zajmującej się obsługą toku studiówprzy ich jednoczesnej fragmentaryzacji sprawia, że działają one w dużej mierze autarkicznie i niezależnie od siebie - wszak każda z nich pełni rolę podrzędną wobec swojej jednostki administracyjnej. Utrudniałoby to $\mathrm{w}$ dużym stopniu proces pozyskiwania informacji, w przypadku gdyby administracja centralna zdecydowała się na taki krok.

Wydaje się nam, że utworzenie kanału dla przepływu takich informacji byłoby z korzyścią nie tylko dla pracowników dziekanatów, ale także dla studentów i samych uczelni. Stowarzyszenie Forum Dziekanatów jest takim kanałem - funkcjonuje bowiem jako niezależny podmiot, który może nawiązywać relacje tak z uczelniami, jak organizacjami zrzeszającymi uczelnie czy zinstytucjami państwowymi (zwłaszcza z MNiSW). W tym nowym układzie daje pracownikom dziekanatów możliwość zabrania głosu w sprawach, które bezpośrednio dotyczą ich pracy, w układzie partnerskich relacji, w którym obie strony tego procesu - adresat i odbiorca - są równe. Paradoksalnie płaszczyzną do jej nabycia stał się trzeci sektor z całym jego instrumentarium narzędzi ułatwiających włączenie się w proces stanowienia prawa. Obie strony mogą w ten sposób przełamać hierarchiczny układ relacji funkcjonujący na większości uczelni, a pracownicy dziekanatów zyskują 
podmiotowość, której często jako pracownicy administracyjni, czyli tzw. niebędący (tzn. niebędący nauczycielami akademickimi ${ }^{32}$ ) po prostu nie mają.

\section{Bibliografia}

\section{Literatura}

P. Dańczak, Decyzja administracyjna w indywidualnych sprawach studentów i doktorantów, Warszawa 2015.

P. Dańczak, J. Wyporska-Frankiewicz, Wszczęcie postępowania administracyjnego w sprawach studenckich i doktoranckich. Zagadnienia wybrane, [w:] J. Tarno, A. Szot, P. Pokorny (red.), Specyfika postępowań administracyjnych w sprawach z zakresu szkolnictwa wyższego i nauki, Lublin 2016.

M. Hauser, Odpowiednie stosowanie przepisów prawa. Uwagi porzadkujące, „Przegląd Prawa i Administracji" 2005, 45.

K. Serafin, Skuteczna komunikacja w podmiotach administracji publicznej, „Studia Ekonomiczne" 2013, 141.

R. Sojak, Dziekanat w przestrzeni instytucjonalnej uniwersytetu - w stronę komunikacji symetrycznej, [w:] K. Górak-Sosnowska, R. Pajewska-Kwaśny (red.), Dziekanat w procesie zmian. Nowa rzeczywistość prawna i organizacyjna, Warszawa 2019.

A. Stoczkiewicz, L. Szypulska-Czkwianianc, Zasady wspótpracy administracji centralnej z dziekanatami na przykładzie Politechniki Warszawskiej, [w:] K. Górak-Sosnowska, R. Pajewska-Kwaśny (red.), Dziekanat w procesie zmian. Nowa rzeczywistość prawna i organizacyjna, Warszawa 2019.

J. Grądziel-Wójcik, Dziekanat a jakość ksztatcenia. Dobre praktyki Wydziatu Filologii Polskiej i Klasycznej UAM, [w:] K. Górak-Sosnowska, R. Pajewska-Kwaśny (red.), Dziekanat w procesie zmian. Nowa rzeczywistość prawna i organizacyjna, Warszawa 2019.

L. Klat-Wertelecka, Organy szkoty wyższej w postępowaniu administracyjnym, [w:] J. Blicharz, A. Sus, A. Chrisidu-Budnik (red.), Zarządzenia szkoła wyższa, Wrocław 2014.

E. Wiśniewska, K. Górak-Sosnowska, Dylematy postępowania administracyjnego w szkołach wyższych na gruncie obowiązujących przepisów prawnych, [w:] K. Górak-Sosnowska, R. Pajewska-Kwaśny (red.), Dziekanat w procesie zmian. Nowa rzeczywistość prawna i organizacyjna, Warszawa 2019.

K. Sobieralski, Milczenie jako prawna forma niedziatania administracji - konsekwencje procesowe, [w:] J. Korczak (red.), Cywilizacja administracji publicznej, Wrocław 2018.

32 W ten sposób definiuje się w ustawie p.s.w.in. i w aktach wewnętrznych uczelni pracowników administracyjnych i technicznych. Zdając sobie sprawę z tego, że dzięki temu możliwe jest całościowe ujęcie wszystkich pracowników uczelni (każdy bez wyjątku mieści się w kategorii nauczycieli akademickich albo dopełniającej ją kategorii pracowników niebędących nauczycielami akademickimi), jednak określenie w sposób wykluczający osób, które i tak są niżej w uczelnianej hierarchii, dodatkowo potęguje różnicę (a czasami przepaść) między tymi dwoma światami - tj. pracowników naukowych i administracyjnych. 
W. Chrościelewski, Z. Kmieciak (red.), Kodeks postępowania administracyjnego. Komentarz, Lex 2019.

\section{Akty prawne}

Ustawa z dnia 14 czerwca 1960 r. Kodeks postępowania administracyjnego (tekst jedn. Dz.U. z 2018 r., poz. 2096 z późn. zm.).

Ustawa z dnia 20 lipca 2018 r. Prawo o Szkolnictwie Wyższym i Nauce (Dz.U. z 2018 r., poz. 1668 z poźn. zm.).

Rozporządzenie Ministra Nauki i Szkolnictwa Wyższego z dnia 27 września 2018 r. w sprawie studiów (Dz.U. z 2018 r., poz. 1861 z późn. zm.).

\section{Inne źródła}

Strona internetowa Forum Dziekanatów: http://dziekanaty.pl

Strona internetowa Stowarzyszenia Forum Dziekanatów: http://forum-dziekanatow.pl Raport z konsultacji publicznych i opiniowania projektu rozporządzenia Ministra Nauki i Szkolnictwa Wyższego w sprawie studiów, MNiSW, 17.09.2018 r.

Zestawienie uwag do projektu rozporządzenia Ministra Nauki i Szkolnictwa Wyższego w sprawie studiów zgłoszonych w ramach opiniowania, MNiSW, 17.09.2018 r. 